Zeszyty Naukowe Szkoły Głównej Gospodarstwa Wiejskiego

Ekonomika i Organizacja Gospodarki Żywnościowej nr 119, 2017: 141-153

DOI 10.22630/EIOGZ.2017.119.30

Krystyna Krzyżanowska

Szkoła Główna Gospodarstwa Wiejskiego w Warszawie

Wydział Nauk Ekonomicznych

\title{
Organizowanie się rolników w grupy i organizacje producentów w obszarze rolnictwa
}

\section{Wstęp}

Jednym z kluczowych problemów polskiego rolnictwa jest rozdrobnienie agrarne na polskiej wsi. W Polsce w 2012 roku funkcjonowało 1476,7 tys. gospodarstw rolniczych o powierzchni powyżej 1 ha użytków rolnych, w tym 780,2 tys. stanowiły gospodarstwa o powierzchni do 5 ha [Baer-Nawrocka, Poczta 2014, s. 99, Dembek i in. 2015, s. 197]. Przeważały gospodarstwa małe, sprzedające na rynek niewielkie partie towarów lub produkujące wyłącznie na samozaopatrzenie.

Kolejną słabą stroną polskiego rolnictwa jest bardzo niski stan zorganizowania producentów w grupy i organizacje. Rolnicy produkują dobrej jakości produkty rolne i sprzedają je najczęściej pośrednikom, którzy opanowali znaczną część rynku. Sprzedając w sposób niezorganizowany, również zakładom przetwórczym i firmom handlowym, rolnicy znajdują się na przegranej pozycji, ponieważ oferowane partie towaru są z reguły niewielkie i niejednorodne [Brodzińska 2009, s. 159]. Możliwości konkurowania pojedynczych gospodarstw rolniczych na rynkach rolno-żywnościowych stają się coraz bardziej ograniczone, a w konsekwencji ich siła przetargowa systematycznie maleje. Jednym z pomysłów na poprawę sytuacji $\mathrm{w}$ tym zakresie jest wspieranie procesu powstawania grup/organizacji w branżach rolniczych. Zakłada się, że integracja pozioma rolników będzie prowadzić do wzmocnienia ich siły przetargowej, a co za tym idzie - do wzrostu dochodów i poprawy kondycji finansowej gospodarstw domowych. Ponadto współpraca między rolnikami może przynieść obniżenie kosztów produkcyjnych i marketingowych, poprawę jakości i wydajności produkcji rolnej [Krzyżanowska 2003a, s. 12]. Podejmowanie działań zespołowych w rolnictwie 


\section{2}

jest w pełni uzasadnione, ponieważ stanowi również punkt wyjścia do pionowych działań integracyjnych polegających na możliwości przejmowania przez grupy/ organizacje branż rolniczych funkcji handlu pierwotnego, a nawet wstępnego przetwórstwa, przyczyniając się $\mathrm{w}$ ten sposób do zmniejszenia nierównowagi $\mathrm{w}$ układzie sił przetargowych na poziomie producenta rolnego [Krzyżanowska 2016, s. 6]. Celem powstawania grup/organizacji producentów w branży rolniczej powinno być nie tylko dążenie do obniżania kosztów produkcji i zwiększania produktywności czynników wytwórczych, ale także możliwość optymalizacji kosztów transakcyjnych (poszukiwania informacji, przetwarzania, zawierania i monitorowania transakcji, egzekwowania zobowiązań). Współdziałanie producentów może również ograniczyć rolę pośredników i przyczynić się do zwiększenia dochodów oraz budowania stabilniejszej pozycji na rynku [Trajer, Krzyżanowska 2014, s. 328].

\section{Cel i metodyka badań}

Celem opracowania było rozpoznanie stanu i regionalnego zróżnicowania integracji producentów w branżach rolniczych, preferencji dotyczących wyboru form prawnych prowadzonych działalności, przedstawienie zakresu przyznanej pomocy finansowej ze środków krajowych i Unii Europejskiej (UE) oraz możliwości wsparcia finansowego w perspektywie 2014-2020. W artykule wykorzystano dane wtórne pochodzące z Krajowego Ośrodka Wsparcia Rolnictwa (KOWR), Ministerstwa Rolnictwa i Rozwoju Wsi (MRiRW), Agencji Restrukturyzacji i Modernizacji Rolnictwa (ARiMR) oraz literaturę przedmiotu. Wyniki analizy przedstawiono $\mathrm{w}$ formie opisowej, tabelarycznej i graficznej.

\section{Dynamika rozwoju grup i organizacji producentów w obszarze rolnictwa}

Liczba grup i organizacji producentów w obszarze rolnictwa do 2013 roku systematycznie wzrastała, a następnie zaczęła spadać. Szczegółowe dane na ten temat przedstawiono $\mathrm{w}$ tabeli 1 .

Po 2013 roku systematycznie zmniejszała się liczba grup/organizacji producentów branż rolniczych. Największy spadek odnotowano w grupach producentów rolnych, gdzie ich liczba w 2017 roku w porównaniu do roku 2013 zmniejszyła się o 372 podmioty, co stanowi $26,9 \%$, w grupach/organizacjach producentów owoców i warzyw w tym samym czasie zaobserwowano natomiast mniejsze spadki, a mianowicie w ciągu czterech lat ubyło 31 podmiotów, co stanowi 9,6\% wszystkich grup i organizacji. 
Tabela 1

Liczba grup/organizacji producentów branż rolniczych w Polsce w latach 2004-2016

\begin{tabular}{|c|c|c|c|c|}
\hline Lata & $\begin{array}{c}\text { Grupy } \\
\text { producentów } \\
\text { rolnych }\end{array}$ & $\begin{array}{c}\text { Wstępnie uznane } \\
\text { grupy producen- } \\
\text { tów owoców } \\
\text { i warzyw }\end{array}$ & $\begin{array}{c}\text { Uznane organiza- } \\
\text { cje producentów } \\
\text { owoców i warzyw }\end{array}$ & Ogółem \\
\hline 2004 & 94 & 24 & 8 & 126 \\
\hline 2005 & 120 & 45 & 7 & 172 \\
\hline 2006 & 157 & 64 & 6 & 227 \\
\hline 2007 & 252 & 83 & 5 & 340 \\
\hline 2008 & 383 & 114 & 5 & 502 \\
\hline 2009 & 509 & 155 & 21 & 685 \\
\hline 2010 & 636 & 171 & 39 & 846 \\
\hline 2011 & 831 & 233 & 54 & 1108 \\
\hline 2012 & 985 & 238 & 78 & 1301 \\
\hline 2013 & 1382 & 215 & 106 & 1703 \\
\hline 2014 & 1351 & 169 & 142 & 1662 \\
\hline 2015 & 1295 & 110 & 195 & 1600 \\
\hline 2016 & 1322 & 52 & 238 & 1612 \\
\hline 2017 & 1010 & b.d. & b.d. & b.d. \\
\hline
\end{tabular}

Źródło: Opracowanie własne na podstawie danych MRiRW i KOWR.

Jedną z przyczyn takiego stanu rzeczy mogło być wprowadzenie ustawy z dnia 11 września 2015 roku o zmianie ustawy o grupach producentów rolnych i ich związkach, która zobowiązuje podmioty do corocznego składania sprawozdania dotyczącego obrotu produktem, oraz rozszerza dotychczasowe ograniczenie posiadania nie więcej niż $20 \%$ głosów na zgromadzeniu wspólników. Zgodnie z art. 4 ustawy zmieniającej, każda grupa producentów rolnych zarejestrowana przed dniem wejścia w życie ustawy musiała złożyć wniosek o potwierdzenie spełnienia warunków uznania jej za grupę producentów, w przeciwnym razie była wykreślana z rejestru [Chlebicka 2017, s. 266]. Aby rozpoznać autentyczne powody zmniejszania się liczby podmiotów podejmujących działania zespołowe, należałoby przeprowadzić badania empiryczne.

Szczegółowy wykaz grup/organizacji branż rolniczych według województw przedstawiono $\mathrm{w}$ tabeli 2 .

Zainteresowanie rolników współdziałaniem $\mathrm{w}$ grupach producentów rolnych było zróżnicowane przestrzennie. Do 1.03.2017 roku najwięcej grup producentów rolnych powstało na terenie województwa wielkopolskiego $(30,6 \%)$, na drugim miejscu uplasowało się województwo dolnośląskie (10,1\%), a miejsce trzecie zajęło województwo kujawsko-pomorskie (9,0\%). Najmniejsze zaintere- 


\section{4}

Tabela 2

Grupy/organizacje branż rolniczych według województw

\begin{tabular}{|l|c|c|c|c|c|c|c|c|}
\hline \multirow{2}{*}{ Województwo } & \multicolumn{2}{|c|}{$\begin{array}{c}\text { Grupy producen- } \\
\text { tów rolnych } \\
\text { [stan na } \\
1.03 .2017 \text { ] }\end{array}$} & $\begin{array}{c}\text { Grupy producen- } \\
\text { tów rolnych } \\
\text { [stan na } \\
15.09 .2017]^{*}\end{array}$ & $\begin{array}{c}\text { Wstępnie uzna- } \\
\text { ne grupy produ- } \\
\text { centów owoców } \\
\text { i warzyw } \\
\text { [stan na } \\
31.12 .2016]\end{array}$ & $\begin{array}{c}\text { Uznane organi- } \\
\text { zacje producen- } \\
\text { tów owoców } \\
\text { i warzyw } \\
\text { [stan na } \\
1.12 .2016]\end{array}$ \\
\cline { 2 - 11 } & liczba & odsetek & liczba & odsetek & liczba & odsetek & liczba & odsetek \\
\hline Dolnośląskie & 132 & 10,1 & 94 & 9,3 & 4 & 7,7 & 6 & 2,5 \\
\hline $\begin{array}{l}\text { Kujawsko- } \\
\text {-pomorskie }\end{array}$ & 118 & 9,0 & 77 & 7,6 & 5 & 9,6 & 34 & 14,3 \\
\hline Lubelskie & 33 & 2,4 & 27 & 2,7 & 5 & 9,6 & 25 & 10,5 \\
\hline Lubuskie & 65 & 5,0 & 45 & 4,5 & - & - & 5 & 2,1 \\
\hline Lódzkie & 37 & 2,7 & 80 & 7,8 & 4 & 7,7 & 15 & 6,3 \\
\hline Małopolskie & 19 & 1,5 & 17 & 1,7 & - & - & 11 & 4,6 \\
\hline Mazowieckie & 78 & 6,0 & 75 & 7,4 & 18 & 34,7 & 72 & 30,3 \\
\hline Opolskie & 89 & 6,7 & 79 & 7,8 & 1 & 1,9 & 4 & 1,7 \\
\hline Podkarpackie & 43 & 3,3 & 39 & 3,9 & 3 & 5,8 & 3 & 1,3 \\
\hline Podlaskie & 43 & 3,3 & 26 & 2,6 & - & & 1 & 0,4 \\
\hline Pomorskie & 68 & 5,2 & 41 & 4,1 & 1 & 1,9 & 6 & 2,5 \\
\hline Śląskie & 24 & 1,8 & 24 & 2,4 & 2 & 3,8 & 2 & 0,9 \\
\hline Świętokrzyskie & 15 & 1,5 & 8 & 0,8 & 2 & 3,8 & 12 & 5,0 \\
\hline $\begin{array}{l}\text { Warmińsko- } \\
\text {-mazurskie }\end{array}$ & 82 & 6,3 & 57 & 5,6 & - & - & 2 & 0,8 \\
\hline Wielkopolskie & 402 & 30,6 & 295 & 29,2 & 6 & 11,6 & 40 & 16,8 \\
\hline $\begin{array}{l}\text { Zachodnio- } \\
\text {-pomorskie }\end{array}$ & 60 & 4,6 & 26 & 2,6 & 1 & 1,9 & - & - \\
\hline Ogółem & 1308 & 100,0 & 1010 & 100,0 & 52 & 100,0 & 238 & 100,0 \\
\hline
\end{tabular}

Źródło: Opracowanie własne na podstawie danych KOWR i Sprawozdania z działalności Agencji Rynku Rolnego w 2016 r., Warszawa 2017, s. 153-154 oraz *Informatora Krajowego Związku Grup Producentów Rolnych 2017, nr 1, s. 7-8.

sowanie współdziałaniem w grupach przejawiali rolnicy mieszkający na terenie województw świętokrzyskiego $(1,5 \%)$ i małopolskiego $(1,5 \%)$.

\section{Charakterystyka grup producentów rolnych}

Grupy producentów rolnych według kierunku produkcji przedstawiono na rysunku 1. 


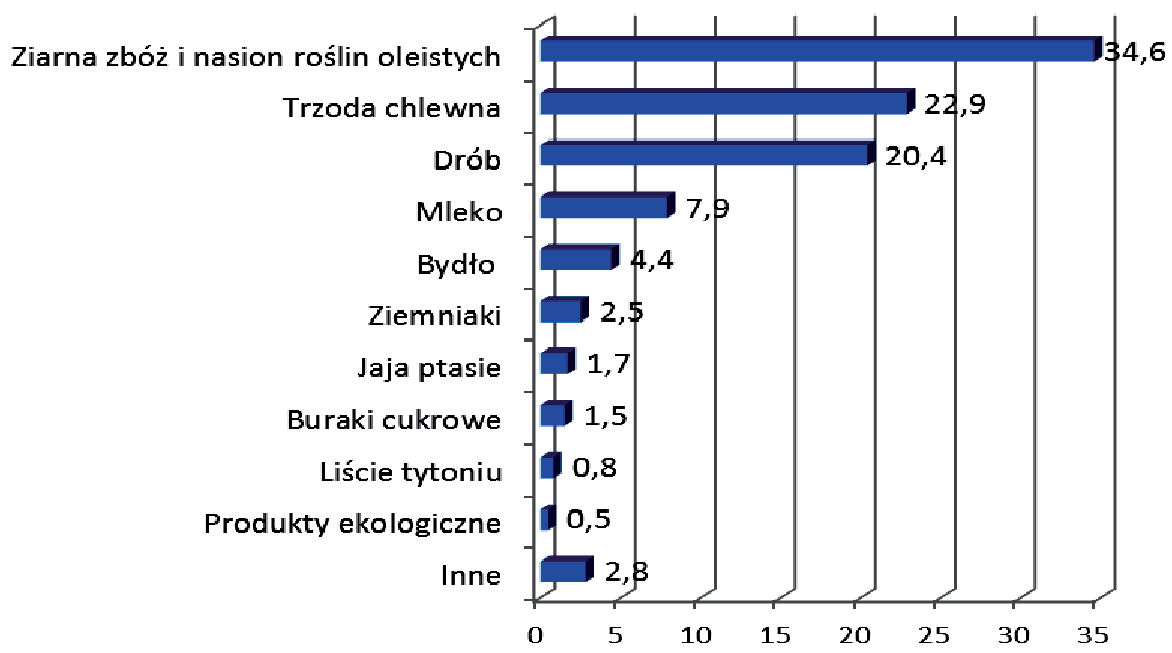

\section{Rysunek 1}

Odsetek grup producentów rolnych według kierunku produkcji [stan na 1.03.2017 r.] Źródło: Opracowanie własne na podstawie danych ARR.

Dominującą pozycję zajmowały grupy producentów ziaren zbóż i nasion roślin oleistych. Na drugim miejscu uplasowały się grupy producentów trzody chlewnej, trzecie miejsce zajęli producenci drobiu. W kategorii ,inne” znaleźli się m.in. producenci roślin uprawianych na cele energetyczne, roślin ozdobnych, materiału siewnego i sadzeniaków, miodu naturalnego i produktów pszczelich, owiec i kóz, roślin przeznaczonych do produkcji zielarskiej lub farmaceutycznej oraz królików. Szczegółowe informacje dotyczące charakterystyki grup producentów rolnych w układzie wojewódzkim przedstawiono w tabeli 3.

Na trzydzieści pięć produktów i grup produktów, dla których mogą być tworzone grupy producentów rolnych, jak dotychczas grupy powstały w dwudziestu dwóch z nich. Zdecydowana większość to grupy następujących produktów: ziarno zbóż i nasiona roślin oleistych, trzoda chlewna i drób. Producenci mleka, ziemniaków, bydła i tytoniu zorganizowani są w kilkunastu grupach, z kolei rolnicy wytwarzający pozostałe produkty utworzyli zaledwie pojedyncze grupy.

Najwięcej grup producentów rolnych produkujących ziarno zbóż i nasiona roślin oleistych powstało w województwach: wielkopolskim (20,3\%), dolnośląskim $(19,0 \%)$, opolskim $(13,3 \%)$, kujawsko-pomorskim (11,5\%) i zachodniopomorskim $(9,5 \%)$. W grupy producentów trzody chlewnej zorganizowali się rolnicy głównie w województwach wielkopolskim (55,8\%), kujawsko-pomorskim $(9,3 \%)$ i mazowieckim $(7,9 \%)$. Producenci drobiu utworzyli grupy przede wszystkim w takich województwach, jak: warmińsko-mazurskie $(15,0 \%)$, wielkopolskie $(12,4 \%)$, lubuskie $(10,9 \%)$, podlaskie $(10,5 \%)$ i mazowieckie $(9,4 \%)$. 
Tabela 3

Charakterystyka grup producentów rolnych według województw [stan na 1.03. 2017 r.]

\begin{tabular}{|c|c|c|c|c|c|c|c|c|c|c|c|}
\hline \multirow[b]{2}{*}{ Województwo } & \multicolumn{11}{|c|}{ Kierunek produkcji } \\
\hline & 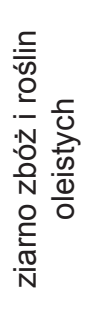 & $\begin{array}{l}\frac{\pi}{2} \\
\frac{2}{0} \\
\frac{0}{0} \\
0 \\
\frac{\pi}{0} \\
\stackrel{N}{N}\end{array}$ & 음 & $\frac{\frac{\partial}{\omega}}{\varepsilon}$ & $\begin{array}{l}\frac{\bar{x}}{\frac{\sigma}{C}} \\
\frac{\delta}{d} \\
\frac{d}{N}\end{array}$ & 옿 & 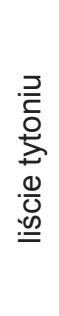 & $\begin{array}{l}\frac{0}{2} \\
\frac{\pi}{0} \\
\frac{\pi}{2} \\
\frac{\pi}{0}\end{array}$ & 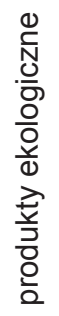 & 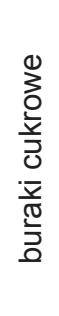 & $\stackrel{\mathscr{Q}}{\subseteq}$ \\
\hline Dolnośląskie & 86 & 1 & 21 & 3 & 13 & 2 & 1 & 1 & 1 & 1 & 2 \\
\hline $\begin{array}{l}\text { Kujawsko- } \\
\text {-pomorskie }\end{array}$ & 52 & 28 & 13 & 4 & 3 & 9 & 1 & - & - & 5 & 3 \\
\hline Lubelskie & 8 & 10 & 3 & - & - & 2 & 4 & - & 2 & 1 & 3 \\
\hline Lubuskie & 21 & 5 & 29 & 7 & - & 1 & - & 2 & - & - & 2 \\
\hline Łódzkie & 5 & 14 & 12 & 2 & - & 1 & - & 1 & - & - & - \\
\hline Małopolskie & 7 & 2 & 3 & - & - & - & 3 & 1 & - & - & 3 \\
\hline Mazowieckie & 5 & 24 & 25 & 14 & 3 & 1 & - & 5 & - & - & 1 \\
\hline Opolskie & 60 & 9 & 12 & - & 2 & - & - & 2 & - & 3 & 1 \\
\hline Podkarpackie & 14 & 4 & 8 & 4 & - & 2 & 1 & 2 & - & 2 & 6 \\
\hline Podlaskie & 2 & 7 & 28 & 1 & - & - & 1 & 2 & 1 & - & 1 \\
\hline Pomorskie & 24 & 12 & 16 & 5 & 5 & 2 & - & - & - & 1 & 3 \\
\hline Śląskie & 7 & 3 & 10 & 2 & - & - & - & 1 & - & - & 1 \\
\hline Świętokrzyskie & - & 1 & 8 & 2 & - & 1 & - & - & 2 & - & 1 \\
\hline $\begin{array}{l}\text { Warmińsko- } \\
\text {-mazurskie }\end{array}$ & 26 & 10 & 40 & - & - & 3 & - & 1 & - & - & 2 \\
\hline Wielkopolskie & 92 & 167 & 33 & 53 & 6 & 34 & - & 3 & 1 & 6 & 7 \\
\hline $\begin{array}{l}\text { Zachodnio- } \\
\text {-pomorskie }\end{array}$ & 43 & 2 & 6 & 7 & - & - & - & 1 & - & - & 1 \\
\hline $\begin{array}{l}\text { Ogółem } \\
N=1308\end{array}$ & 452 & 299 & 267 & 104 & 32 & 58 & 11 & 22 & 7 & 19 & 37 \\
\hline
\end{tabular}

Źródło: Opracowanie własne na podstawie danych KOWR [dostęp: 25.09.2017].

Grupy producentów rolnych muszą zarejestrować się jako podmioty gospodarcze i moga przybierać różne formy prawne: spółdzielni, spółki prawa handlowego, zrzeszenia i stowarzyszenia. Każda z tych form działa na podstawie innych uregulowań ustawowych. Przy prowadzeniu działalności gospodarczej najlepsze są spółdzielnie i spółki z o.o. Z kolei zrzeszenia i stowarzyszenia najlepiej sprawdzają się przy realizacji działań społecznych. Preferencje producentów rolnych w tym zakresie przedstawiono na rysunku 2. 


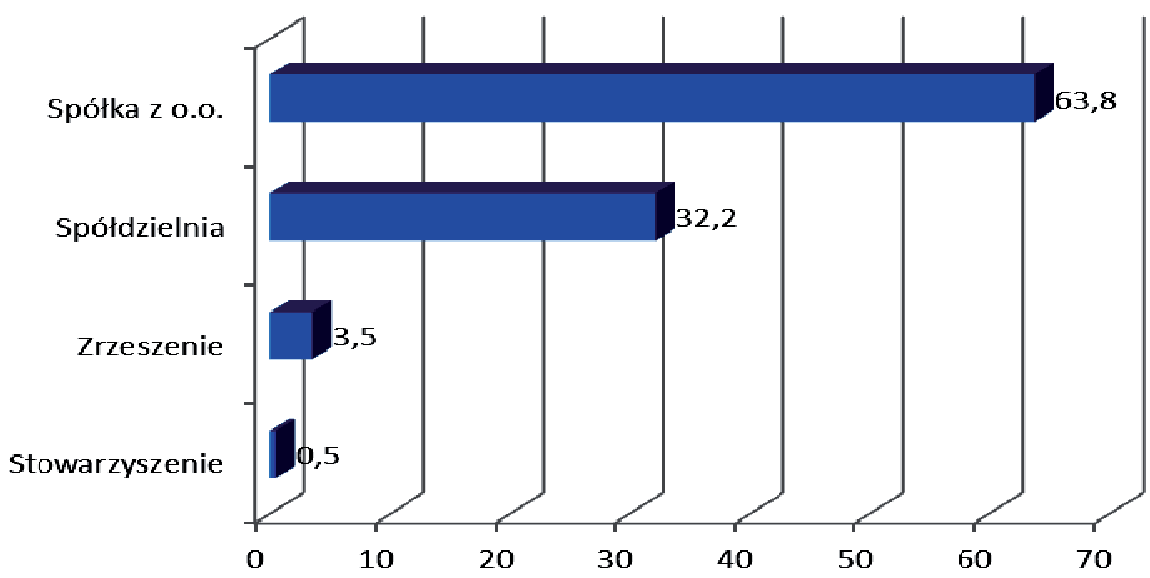

\section{Rysunek 2}

Odsetek grup producentów rolnych według form prawnych [stan na 1.03.2017] Źródło: Opracowanie własne na podstawie danych KOWR [dostęp: 25.09.2017].

Wśród form prawnych najliczniej reprezentowane były spółki z o.o. i spółdzielnie, odpowiednio 61,9\% i 26,7\%. Wyraźnie spadło zainteresowanie zrzeszeniami i stowarzyszeniami (tab. 4).

\section{Tabela 4}

Liczba grup producentów rolnych według formy prawnej w poszczególnych produktach lub grupach produktów [stan na 1.03. 2017 r.]

\begin{tabular}{|l|c|c|c|c|c|}
\hline \multirow{2}{*}{ Kierunek produkcji } & \multirow{2}{*}{ Ogółem } & \multicolumn{4}{|c|}{ Forma prawna } \\
\cline { 3 - 6 } & & $\begin{array}{c}\text { spółka } \\
\text { z o.o. }\end{array}$ & spółdzielnia & zrzeszenie & $\begin{array}{c}\text { stowarzy- } \\
\text { szenie }\end{array}$ \\
\hline $\begin{array}{l}\text { Ziarno zbóż i nasion } \\
\text { roślin oleistych }\end{array}$ & 452 & 336 & 109 & 6 & 1 \\
\hline Trzoda & 299 & 114 & 153 & 28 & 4 \\
\hline Drób & 267 & 225 & 42 & - & - \\
\hline Mleko & 104 & 51 & 52 & 1 & - \\
\hline Bydło & 58 & 17 & 40 & 1 & - \\
\hline Ziemniaki & 32 & 28 & 4 & - & - \\
\hline Jaja ptasie & 22 & 19 & 3 & - & - \\
\hline Buraki cukrowe & 19 & 14 & 5 & - & - \\
\hline Liście tytoniu & 11 & 2 & - & 9 & - \\
\hline Produkty ekologiczne & 7 & 2 & 3 & - & 2 \\
\hline Inne & 37 & 27 & 9 & 46 & - \\
\hline Ogółem & $\mathrm{N}=1308$ & 835 & 420 & & 7 \\
\hline
\end{tabular}

Źródło: Opracowanie własne na podstawie danych KOWR [dostęp 29.09.2017]. 
Spółki z o.o. preferowali producenci ziaren zbóż i nasion roślin oleistych oraz drobiu, a spółdzielnie producenci trzody chlewnej, ziaren zbóż i nasion roślin oleistych oraz mleka.

\section{Charakterystyka grup/organizacji producentów owoców i warzyw}

Struktura grup/organizacji producentów owoców i warzyw według kierunku produkcji przedstawiona została na rysunku 3.

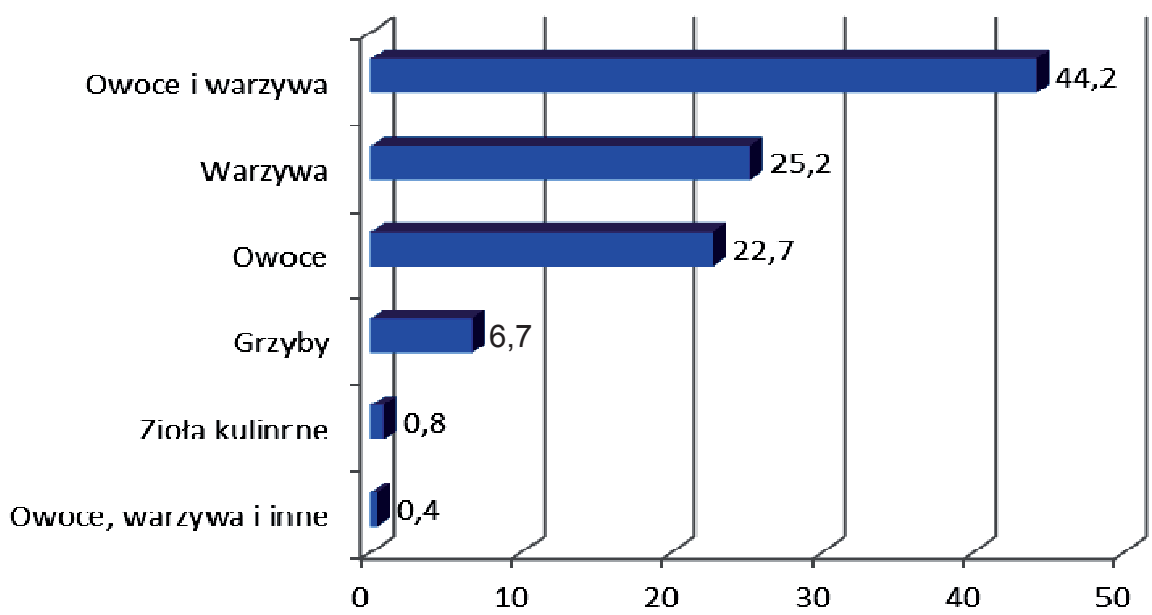

\section{Rysunek 3}

Odsetek grup/organizacji producentów owoców i warzyw według kierunku produkcji [stan na 31.12.2016 r.]

Źródło: Opracowanie własne na podstawie Sprawozdania z działalności Agencji Rynku Rolnego w 2016 r., Warszawa 2017, s. 154.

Najwięcej grup/organizacji powstało w kategorii „owoce i warzywa”, na drugim miejscu znaleźli się producenci warzyw, a trzecie zajęli producenci owoców.

Polskie prawo przewiduje kilka form prawnych zrzeszania się producentów. Preferencje producentów owoców i warzyw dotyczące formy prawnej przedstawiono w tabeli 5.

W 2016 roku preferowaną przez producentów owoców i warzyw formą współpracy była spółka z o.o., a więc zupełnie odmiennie niż w 2002 roku, kiedy to dominowały zrzeszenia i stowarzyszenia, a spółki z o.o. stanowiły tylko 4,2\% 
Tabela 5

Grupy/organizacje producentów owoców i warzyw według form prawnych w latach 2002 i 2016

\begin{tabular}{|l|c|c|c|c|}
\hline \multirow{2}{*}{ Forma prawna } & \multicolumn{2}{|c|}{31.12 .2002 r. $^{*}$} & \multicolumn{2}{c|}{26.02 .2016 r. $^{* *}$} \\
\cline { 2 - 5 } & $\mathrm{N}=119$ & $\%$ & $\mathrm{~N}=304$ & $\%$ \\
\hline Spółka z o.o. & 5 & 4,2 & 252 & 83,0 \\
\hline Spółdzielnia & 15 & 12,6 & 24 & 7,9 \\
\hline Zrzeszenie & 47 & 39,5 & 21 & 6,8 \\
\hline Stowarzyszenie & 52 & 43,7 & 7 & 2,3 \\
\hline
\end{tabular}

Źródło: K. Krzyżanowska [2003 s. 231]; Opracowanie własne na podstawie rejestru grup producentów owoców i warzyw, www.arr.gov.pl/data/02100/rejestr_prezesa_arr_26022016.pdf [dostęp: 23.09.2017].

wszystkich form prawnych. Powodem takich wyborów producentów może być mała liczba członków umożliwiająca utworzenie grupy, a także nastawienie tych podmiotów na cele ekonomiczne. Spółdzielnie w swoich założeniach powinny sprzyjać integracji społeczności lokalnych również na takich płaszczyznach, jak: społeczna, kulturalna czy edukacyjna. Kierunek rozwoju form prawnych integracji w polskim rolnictwie nie jest więc $\mathrm{z}$ tego punktu widzenia najlepszy. Z drugiej strony w krajach Europy Zachodniej grupy producentów ewoluują w kierunku instytucji bardziej nastawionych na zysk niż osiaganie innych celów, a głównym problemem działających tam spółdzielni jest pozyskiwanie kapitału. Biznes i cele ekonomiczne zaczynają dominować nad celami społecznymi. Można zatem stwierdzić, że procesy integracyjne w Polsce, jeśli chodzi o reakcje na zmiany w otoczeniu rynkowym, przebiegają w podobnym kierunku [Olszańska 2014, s. 229].

\section{Finansowe wsparcie dla grup/organizacji branż rolniczych ze środków krajowych i Unii Europejskiej}

Według stanu na 30.06.2017 roku wsparcie finansowe dla grup producentów rolnych wynosiło $882,7 \mathrm{mln}$ zł. Do najbardziej aktywnych grup producentów rolnych w pozyskiwaniu środków finansowych z PROW 2007-2013 (działanie 142: „Grupy producentów rolnych”) należeli producenci drobiu (33,0\%), na drugim miejscu znaleźli się producenci trzody chlewnej $(20,0 \%)$ i producenci ziaren zbóż i nasion roślin oleistych (20,0\%) [Dane KOWR za 2107].

W nowej perspektywie finansowej 2014-2020 grupy utworzone w kategorii: drób żywy, mięso i jadalne podroby wyłączone zostały z możliwości wsparcia finansowego, ponieważ uzyskały najwyższą pomoc finansową z PROW 2007- 
-2013, a gospodarstwa specjalizujące się w tej produkcji osiagnęły stosunkowo wysoki poziom rozwoju. W perspektywie finansowej 2014-2020 podwyższono zakres wsparcia dla nowo utworzonych grup producentów rolnych, z obowiązującego w PROW 2004-2006 i 2007-2013 poziomu 5, 5, 4, 3, 2\% od wartości netto przychodów ze sprzedaży, do 10, 8, 6,5, i 4\%, w każdym roku pięcioletniego okresu wsparcia finansowego.

Wsparcie finansowe dla grup/organizacji producentów owoców i warzyw według stanu na 30.06.2017 roku wynosiło 7,8 mld zł, w tym 98,7\% otrzymały wstępnie uznane grupy producentów owoców i warzyw z przeznaczeniem na koszty utworzenia grupy, prowadzenie działalności administracyjnej, pokrycie części kwalifikowanych kosztów inwestycji ujętych w zatwierdzonych planach dochodzenia do uznania, $0,3 \%$ uznane organizacje producentów owoców i warzyw na dofinansowanie funduszu operacyjnego oraz $1,0 \%$ organizacje producentów dostarczające pomidory do przetwórstwa. W nowej perspektywie finansowej 2014 -2020 pomoc finansowa może być realizowana jedynie dla uznanych organizacji producentów owoców i warzyw na dofinansowanie funduszu operacyjnego.

\section{Podsumowanie i wnioski}

1. Poprawa efektywności produkcji rolniczej w warunkach konkurencji rynkowej powinna być troską każdego rolnika. W obecnej trudnej sytuacji ekonomicznej wielu gospodarstw polscy rolnicy powinni poszukiwać nowych rozwiązań umożliwiających pokonanie tych trudności. Jednym ze sposobów jest podejmowanie przez producentów działań zespołowych. Współdziałanie rolników może sprzyjać koncentracji produkcji i kapitału, a w konsekwencji przyczynić się do przemian strukturalnych na wsi. W strategii rozwoju rolnictwa grupy/organizacje producentów branż rolniczych stanowią istotną drogę rozwoju, podobnie jak w krajach Unii Europejskiej.

2. W ramach wsparcia procesów integracyjnych w rolnictwie do 30.06.2017 roku producenci rolni pozyskali 8,7 mld zł, w tym $90 \%$ otrzymały grupy i organizacje w ramach wspólnej organizacji rynku owoców i warzyw. Pozostałe 10\% przekazane zostało z Programu Rozwoju Obszarów Wiejskich dla innych branż, w tym najbardziej aktywni w pozyskiwaniu środków finansowych z PROW 2007-2013 w ramach działania 142 „Grupy producentów rolnych" byli producenci: drobiu, trzody chlewnej, a także ziaren zbóż i nasion roślin oleistych.

3. O dalszym rozwoju grup/organizacji producentów decydować będzie zaś zakres wsparcia finansowego ze środków krajowych i UE, jak również właściwa polityka państwa wspierająca duże podmioty gospodarcze, zdolne do 
konkurowania na globalnych rynkach. Istotne będzie również promowanie sukcesów grup już działających na rynku, podejmowanie działań na rzecz budowania zaufania do innych podmiotów oraz kształtowanie i promowanie właściwych postaw liderów. Producenci powinni otrzymać pomoc merytoryczną ze strony doradców rolniczych, głównie doradców ośrodków doradztwa rolniczego.

4. Problem rozwoju grup/organizacji producentów branż rolniczych jest ważny dla przyszłości polskiej wsi i rolnictwa. Istnieje potrzeba prowadzenia systematycznych badań naukowych o charakterze interdyscyplinarnym. Badania takie miałyby większą wartość teoretyczną i tym samym szerszy wachlarz funkcji aplikacyjnych.

\section{Literatura}

BAER-NAWROCKA A., POCZTA W., 2014: Przemiany w rolnictwie, [w:] Polska wieś 2014. Raport o stanie wsi, Wydawnictwo Scholar, Warszawa, 99.

BRODZIŃSKA K., 2009: Dynamika powstawania i zakres działalności grup producentów rolnych w Polsce, [w:] S. Zawisza (red.),Rozwój przedsiębiorczości i zespołowej działalności gospodarczej w rolnictwie w świetle integracji z Uniq Europejska, Wydawnictwo Uczelniane Uniwersytetu Technologiczno-Przyrodniczego w Bydgoszczy, Bydgoszcz, 159.

CHLEBICKA A., 2017: Organizacje producenckie we Wspólnej Polityce Rolnej-przestanki tworzenia i ewaluacja wsparcia, [w:] A. Chlebicka (red.), Integracja europejska jako determinanta polityki wiejskiej. Aspekty ekonomiczne, Fundacja Programów Pomocy dla Rolnictwa FAPA, Warszawa, 226.

DEMBEK W., PIÓRKOWSKI H., ZIĘTARA W., 2015: Konkurencyjność polskiego rolnictwa a stan i potencjalne zmiany środowiska przyrodniczego obszarów wiejskich, [w:] E.K. Chyłek, M. Pietras (red.), Badania naukowe w procesie ksztattowania polskiej wizji Wspólnej Polityki Rolnej i Wspólnej Polityki Rybackiej, Wydawnictwo Pascal sp. z o.o., Warszawa, 197.

Informator Krajowego Związku Grup Producentów Rolnych 2017: Stan zorganizowania grup producentów rolnych $w$ Polsce, $\mathrm{nr} 1$.

KRZYŻANOWSKA K., 2003a: Przedsiębiorczość zespołowa rolników i jej uwarunkowania, Wydawnictwo SGGW, Warszawa, 12.

KRZYŻANOWSKA K., 2003b: Stan i kierunki rozwoju rolniczych grup producenckich w Polsce, Zeszyty Naukowe Szkoły Głównej Gospodarstwa Wiejskiego. Ekonomika i Organizacja Gospodarki Żywnościowej 48, 231.

KRZYŻANOWSKA K., 2016: Ekonomiczno-społeczne uwarunkowania innowacji w zespotowym działaniu w rolnictwie, Wydawnictwo Szkoły Głównej Gospodarstwa Wiejskiego, Warszawa.

OLSZAŃSKA A., 2014: Procesy integracyjne w agrobiznesie, [w:] S. Urban red., Agrobiznes $i$ biobiznes. Teoria i praktyka, Wydawnictwo Uniwersytetu Ekonomicznego we Wrocławiu, Wrocław, 229. 
Sprawozdanie z działalności Agencji Rynku Rolnego w 2016 r., Warszawa 2017.

TRAJER M., KRZYŻANOWSKA K., 2014: Tendencje zmian na rynku mleka i możliwości wspótdziałania rolników w grupach, Roczniki Naukowe SERiA 16, 4, 328.

www.arr.gov.pl/data/02100/rejestr_prezesa_arr_26022016.pdf (dostęp: 23.09.201).

\title{
Abstrakt
}

Celem opracowania było rozpoznanie stanu i regionalnego zróżnicowania integracji producentów w branżach rolniczych, preferencji dotyczących wyboru form prawnych przedsiębiorstw, przedstawienie zakresu przyznanej pomocy finansowej ze środków krajowych i Unii Europejskiej oraz możliwości wsparcia finansowego $\mathrm{w}$ perspektywie lat 2014-2020. Z przeprowadzonej analizy wyni$\mathrm{ka}$, że według stanu na 30.06.2017 roku wsparcie finansowe dla grup producentów rolnych wynosiło tylko $882,7 \mathrm{mln}$ zł, a dla grup/organizacji producentów owoców i warzyw 7,8 mld zł, w tym $98,7 \%$ otrzymały wstępnie uznane grupy producentów owoców i warzyw. W nowej perspektywie finansowej 2014-2020 grupy producentów rolnych utworzone w kategoriach: drób żywy, mięso i jadalne podroby wyłączone zostały z możliwości wsparcia finansowego, a pomoc w sektorze owoców i warzyw może być realizowana jedynie dla uznanych organizacji producentów na dofinansowanie funduszu operacyjnego.

Słowa kluczowe: grupy producentów rolnych, grupy i organizacje producentów owoców i warzyw, rolnictwo

\section{Farmers organizing into groups and producer organizations in the area of agriculture}

\begin{abstract}
The aim of the study was to identify the state and regional diversification of producers' integration in the agricultural sector, the preferences for the choice of legal forms of companies as well as to present the scope of financial support granted from national and European funds, and the possibility of financial support in the 2014-2020 perspective. According to the analysis, as of June 30, 2017, financial support for agricultural producer groups was only PLN 882.7 million and for fruit and vegetable producer groups / organizations PLN 7.8 billion, including $98.7 \%$ pre-approved groups of fruit and vegetable producers. In the new financial perspective for 2014-2020, agricultural producer groups established in the category of live poultry, meat and edible offal are excluded from
\end{abstract}


financial support, while aid in the fruit and vegetable sector can only be provided to recognized producer organizations for co-financing of the operational fund.

Key words: agricultural producer groups, fruit and vegetables producer groups and organizations, agriculture 